\title{
Banned from the Pacific
}

'It is the way the Pacific's ancient régimes hold onto power. All journalists are under siege. In Fiji, it is an extraordinary assault, coloured by racism, that is tearing apart the media and political system.'

\section{BY BERNADETTE HUSSAIN}

AGENCE FRANCE-PRESSE correspondent Michael Field isn't too popular with authorities in the Pacific. He has already been banned from three island nations, appeared on the blacklist of another and criticised for a number of stories he has done on the region.

The New Zealand-based South Pacific correspondent is the first to admit that covering the Pacific is tough. Field was banned from Tonga in the early $90 \mathrm{~s}$, Kiribati last year, and Nauru this year; he appeared on Fiji Government's blacklist; and he was criticised for his reporting on the ethnic war in the Solomons.

His experience with the Kiribati and Nauru governments have been most recent and the Kiribati affair saw him receive a mention in this year's annual press freedom report by press group Rapporter Sans Frontières (Reporters Without Borders), while a host of protests backed him over Nauru.

Early last year Kiribati President Teburoro Tito declared Field a prohibited migrant because of reports on the environmental mess on Tarawa, including human excrement on its beaches and fuel oil in the main water lens of the atoll.

In a statement in the official Kiribati Gazette last year, Tito said that Field had written "untruths" about the development problems. He said the ban on Field was made on behalf of the people. Tito said the i-Kiribati people respected their country and did not want someone from outside to show disrespect. He added that the people of Kiribati always showed respect to the dignity of other

PACIFIC JOURNALISM REVIEW 7:12001 175 
countries.

In Nauru, he was banned from the Forum apparently because of his stories about the laundering of mafia money through the country.

As for Tonga, Field had been covering it for nearly 20 years and it came as no surprise that police chief Clive Edward banned him from entering the kingdom. Edward claimed that Field had been "culturally offensive", but declined to discuss it. "Now they have the nerve to say my stories are one sided - well whose fault is that?" said Field soon after he was banned.

Tonga removed Field's

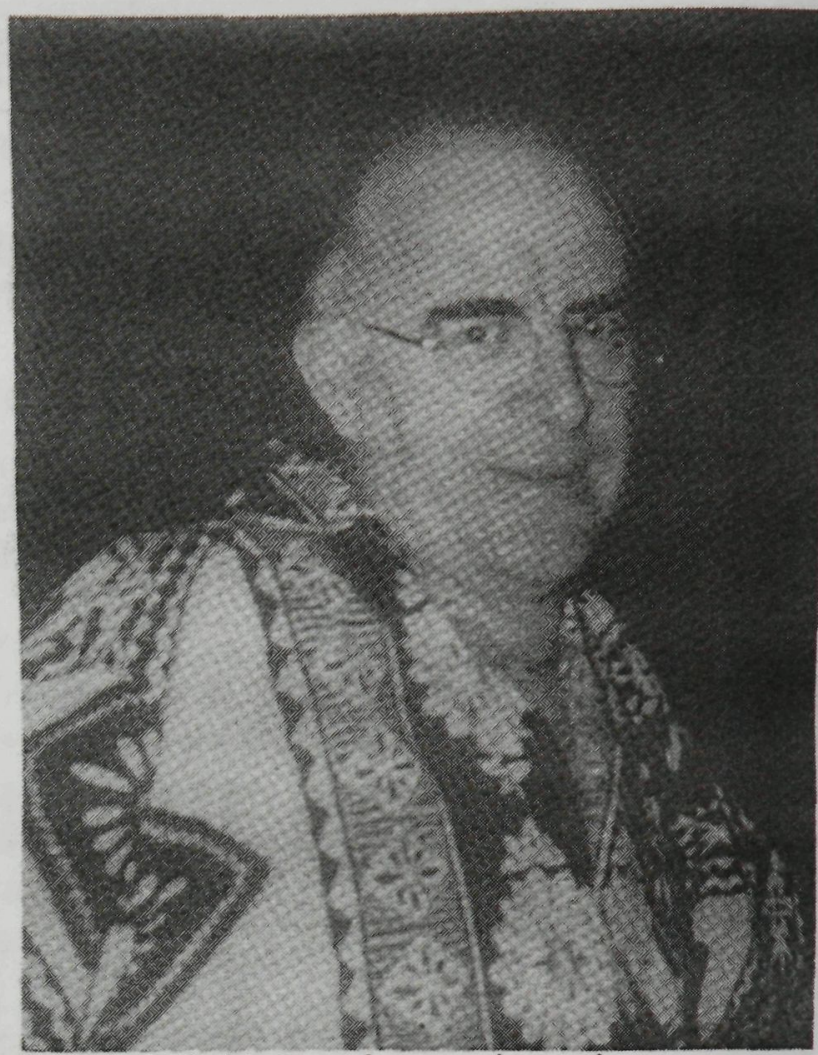

Michael Fleld: Bannings an incentive.

Photo: WANSOLWARA automatic entry status in 1993, apparently in reaction to coverage of the country's pro-democracy movement and Tonga's sale of passports to Asians. But this ban has not failed to stop him, and Field continues to cover Tonga from New Zealand.

Putting the Pacific situation into perspective, Field said the reaction of these countries was not a personal thing.

"It is the way the Pacific's ancient regimes hold onto power. All journalists are under siege. In Fiji it is an extraordinary assault, coloured by racism, that is tearing apart the media and political system," said Field.

He was back in Fiji in August, covering the elections there after his banning from Nauru.

"In the Solomon Islands last year a couple of other journalists and I had gone out to a bridge where ex-Fiji Prime Minister Sitiveni Rabuka was to negotiate a truce. Radio Australia's veteran correspondent Sean Dorney, had come up with an explanation for why Guadalcanal and Malaitan Islanders were at war. 176 PACIFIC JOURNALISM REVIEW 7:1 2001 
The former had a matrilineal society while the Malaitans were aggressively patrilineal.

"I asked George Grey, the leader of the rebels, what it was that he did not like about Malaitans.

"'Do you know what we call them'," he said.

“"Dog sperm'."

Field had no reservations about reporting that. The story came back to Honiara where the local newspaper used it.

As a result of this, the state-owned Solomon Islands Broadcasting Corporation's general manager Johnson Honimae took Grey's comments a step further.

"Overseas journalists don't care what happens as a result of their stories," he said. "If that reporter was in Honiara, he would have been killed," Honimae told the University of the South Pacific's journalism newspaper Wansolwara.

Field says that being kept out of some of these island nations was just part of the ball game.

"These governments, mainly made up of aging chiefly men, do not like the young, university educated people who constitute the Pacific media.

"The Paradise Journalism helps the establishment. Non-Pacific reporters, often on airline freebies declare how beautiful the beaches are, how happy the natives are and how good the singing is in church. Cultures and societies are reduced to one dimension. The problem is that those of us who go beyond it get banned."

But life and reporting goes on for Field who reports on these countries through sources while he works from New Zealand.

"I don't see these bans as hurdles and it just gives me the incentive to work harder and report on the truth."

Bernadette Hussain is features editor of The Fiji Times. 